\section{Bongani Ngqulunga}

Deputy Director of the

Johannesburg Institute for Advanced Study (JIAS),

University of Johannesburg,

Email: ngqulungab@uj.ac.za

DOI: https://dx.doi.

org/10.18820/24150509/

JCH43.v2.1

ISSN 0258-2422 (Print)

ISSN 2415-0509 (Online)

Journal for Contemporary

History

2018 43(2):1-14

(c) Creative Commons With Attribution (CC-BY)

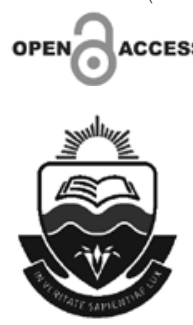

\section{A MANDATE TO LEAD: \\ MANGOSUTHU BUTHELEZI AND THE APPROPRIATION OF PIXLEY KA ISAKA SEME'S LEGACY}

\begin{abstract}
:
This article discusses the appropriation of Seme's name and political legacy by Mangosuthu Buthelezi, the leader of the Inkatha Freedom Party (IFP). While Buthelezi has always invoked Seme's name in his long political career, the analysis in the article focuses on two periods. The first was the 1980s when Buthelezi's political party, Inkatha Yenkululeko Yesizwe, was involved in a fierce competitive struggle for political hegemony with the exiled African National Congress (ANC) and its allies inside the country. During this period, Buthelezi used Seme's name to serve as a shield to protect him from political attacks from his adversaries in the broad ANC alliance. After the advent of democracy in the early 1990s, the political hostilities of the 1980 s between the ANC and the IFP cooled down and the two parties worked together in the Government of National Unity (GNU). It was during this period that Buthelezi gradually moved closer to the ANC, especially under the leadership of its former president, Thabo Mbeki. Although the political circumstances had changed, Buthelezi continued to use Seme's name to advance his political interests. The purpose for appropriating Seme's name however changed. He invoked Seme in order to present himself as belonging to the broad black political tradition as represented by the ANC. I suggest that this change of tune and tack was Buthelezi's tactic to secure himself a respectable position in the pantheon of the liberation struggle. In other words, he was staking a claim for his place in history.
\end{abstract}

Keywords: Appropriation; political legacy; liberation struggle; Zulu nationalism; political competition; Mangosuthu Buthelezi; Inkatha; Pixley ka Isaka Seme; African National Congress; judgment of history.

Sleutelwoorde: Toeëiening; politieke erfenis; vryheidstryd; Zoeloe nasionalisme; politieke wedywering; Mangosuthu Buthelezi; Inkatha; Pixley ka Isaka Seme; African National Congress; historiese oordeel. 
JCH / JEG 43(2) I December / Desember 2018

\section{INTRODUCTION}

Buthelezi has acquired a legendary reputation for interpreting history in a manner that serves his political aims. Writing almost three decades ago, Daphna Golan showed the many instances in which Buthelezi and other leaders of the IFP twisted the meaning of certain historical events and historical figures in Zulu history in a manner that served Buthelezi's political needs. ' For instance, when Buthelezi wanted to assert his political authority over King Zwelithini in the early 1970s he made a claim that historically Zulu kings were above politics. This was a concealed attempt to prevent King Zwelithini from contesting Buthelezi's role in the politics of the emerging KwaZulu Bantustan. When King Zwelithini tried to press his political claims to leadership of the KwaZulu in the 1970s, Buthelezi rebuffed him by claiming that the Zulu monarchy was a non-political entity. Again, when he was faced with political competition from some leaders in Zululand who formed political parties to compete with Inkatha, Buthelezi resorted to his interpretation of history and argued that traditionally Zulus, "made decisions by consensus, and seldom let disputes separate them". ${ }^{2}$

\section{BUTHELEZI'S USE OF HISTORY FOR POLITICAL ENDS}

Several historians, such as Mare and Hamilton, Golan, and Forsyth, have also noted Buthelezi's tendency to justify controversial political stances by claiming that they were supported either by, or in keeping with, the politics and values of venerated former leaders of the ANC, such as John Langalibalele Dube and Albert Luthuli. ${ }^{3}$ In the case of Luthuli, scholars, such as Scott Couper, Luthuli's biographer, in particular have emphatically challenged Buthelezi's claim that Luthuli supported his (Buthelezi's) participation in the Bantustan system. ${ }^{4}$ Couper's rebuttal of Buthelezi's misappropriation of Luthuli's politics and memory follows on refutations by other scholars. ${ }^{5}$

1 Golan, D, "Inkatha and its Use of the Zulu Past". History in Africa 18, 1991, pp. 113-26, p.114.

2 Ibid.

3 Some of the historians who have written persuasively about Buthelezi's various (and sometimes dubious) justifications include Mare, G and G Hamilton, An appetite for power: Buthelezi's Inkatha and South Africa (Johannesburg: Ravan Press, 1987); Mzala, Gatsha Buthelezi: Chief with a double agenda (London: Zed Books, 1988); Golan, D, "Inkatha and its use of the Zulu Past", pp. 113-26; Forsyth, $P$, "The past in the service of the present: The political use of history by Chief ANMG Buthelezi, 1951-1991. South African Historical Journal 26(1), 1992: pp.74-92; J Sithole and S Mkhize, "Truth or lies? Selective memories, imagings, and representations of Chief Albert John Luthuli in recent political discourses", History and Theory, Vol. 39(4), 2000: pp. 69-85; and Couper, S, "Chief Albert Luthuli and the Bantustan question", Journal of Natal and Zulu History 24\&25, 2006-2007, pp. 240-268.

$4 \quad$ S Couper, "Chief Albert Luthuli and the Bantustan Question", pp. 240-268.

5 See in particular Sithole and Mkhize, "Truth or lies? ...", pp. 69-85. 
Other historians have shown, for instance, that Buthelezi has used history at various stages of his development as a political leader in order to address the political exigencies of the time. In this connection, Paul Forsyth identified five main phases of Buthelezi's political career. During each phase, Buthelezi deployed history as a weapon in his political battles. When he started out as a political leader between 1951 and 1968, Buthelezi asserted his "historic" right to rule. He claimed that his ancestors had always played a leading role in the Zulu monarchy and, based on that, history asserted his right as the Zulu king's traditional prime minister. As Forsyth observes, during this phase Buthelezi was politically weak in Zulu politics and needed to establish himself. By the late 1960s and early 1970s, he became bolder and staked his claim to lead the Zulu nation as a whole by once again invoking history. His boldness was not incidental; his capturing of government institutions, created by apartheid. provided him with political power that he did not have before. He used access to power and resources to dispense political patronage and to deal with his political opponents in the Zulu Royal House and in KwaZulu polity generally ${ }^{6}$. By the mid to late 1970s, he began to present himself as the leader of black people in South Africa as a whole and presented a version of history that supported this political ambition. He claimed that the formation of Inkatha had received the blessing of the ANC leadership, which partly explains the use of the ANC colours in Inkatha's political paraphernalia. The impression he sought to create was that his Inkatha was the reincarnation of the banned ANC. ${ }^{8}$ This presentation of Inkatha, as the internal wing of the ANC, was of course unjustified as the developments between the ANC and Inkatha in the late 1970s confirmed. Yet Buthelezi's strategy to project himself as a national leader who carried the banner of the exiled ANC internally and was the standard-bearer of the aspirations of the oppressed seems to have paid dividends. By the late 1970s, opinion polls suggested that those who were surveyed considered Buthelezi to be the most popular leader in Durban, Soweto and Pretoria. ${ }^{9}$ The popularity was not only confined to him. His Inkatha attracted significant levels of support from the late 1970s to the late 1980s. Having started at a low base of 30000 members in 1976, the membership grew to 300000 by

$6 \quad$ Scholars such as Mare and Hamilton, for instance, have discussed in detail the various ways in which Buthelezi used his leadership positions in the apartheid created structures such as the Zulu Territorial Authority and the KwaZulu Legislative Assembly to marginalise political opponents such as King Goodwill Zwelithini who, at the time, wanted a position created for him to become an executive monarch within the Bantustan system. See chapter 3 of Mare and Hamilton, An appetite for power.

$7 \quad$ Forsyth discusses this phase of Buthelezi's political career and argues that Buthelezi was trying to build a popular support base beyond the confines of his Zulu constituency. See Forsyth, "The past in the service of the present', pp. 81-86, and Mare and Hamilton, An appetite for power. See Sithole and Mkhize, "Truth or lies?...", p. 76.

9 See Piper, L, "Nationalism without a ation: The rise and fall of Zulu Nationalism in South Africa's transition to democracy, 1975-1999", Nations and Nationalism 8(1), 2002, pp. 73-94, here p. 79. 
1980; 985000 by 1984 and 1,5 million in $1987 . .^{10}$ The phenomenal growth in the membership reflected the success of Buthelezi's strategy to project his party as the standard-bearer of the internal opposition to apartheid. There is also evidence that some people were coerced to join Inkatha especially during the violent decade of the 1980s and the early 1990s."

It was only in the aftermath of the contentious 1979 meeting between leaders of the ANC and Inkatha that the enmity between the two organisations began. ${ }^{12}$ The estrangement reached its apogee with the formation of popular organisations aligned to the ANC, such as the Congress of South African Students (COSAS), the United Democratic Front (UDF) and later on the Congress of South African Trade Unions (COSATU). These organisations challenged Buthelezi's political claims of being the spokesperson of the oppressed majority inside the country and competed for the same political constituency he was trying to monopolise for himself and his Inkatha. They pointed at his leadership of the KwaZulu Bantustan as endorsement of the Bantustan system, thereby challenging his claim of fighting the system from the inside. ${ }^{13}$ Faced with the new political reality, Buthelezi changed tack. ${ }^{14}$ From the mid-1980s, he began to present a version of history that sought to diminish the role of the banned ANC in the struggle for liberation in South Africa. ${ }^{15}$ It was also during that period that Buthelezi began to assertively appropriate the names, memories and legacies of certain past ANC leaders to bolster his political position. In several speeches, Buthelezi made a bold claim that the leadership of the ANC in exile was not the rightful heirs to the founders of the ANC, such as Seme and Dube. He argued that he was the rightful heir and that his party, Inkatha, was the continuation of the ANC of Seme, Dube and Luthuli. ${ }^{16}$ It was also during that period that he particularly claimed the legacy of Seme, contending that he did not only have a familial relationship with Seme, but he was a standard-bearer of his politics.

10 See Sutcliffe $M$ and $\mathrm{P}$ Wellings, "Inkatha and the rest: Black opposition to Inkatha in Durban's townships", African Affairs 87(348), 1988, pp. 325-360, here p. 327.

11 See, for instance, Moloi, T, Black students politics in South Africa, 1990-1996. In: The road to democracy in South Africa, Volume 6 (1990-1996), Part 2 (Pretoria: Unisa Press, 2013), pp. 11831235.

12 For detailed discussion of the 1979 meeting, see chapter 7 of Mzala, Gatsha Buthelezi and chapter 5 of Mare and Hamilton, An appetite for power.

13 See Seekings J, The UDF: A history of the United Democratic Front in South Africa, 1983-1991 (Cape Town: David Philip Publishers, 2000), pp. 65-66.

14 Piper, "Nationalism without a nation ...", pp. 73-94. Also, see Sutcliffe and Wellings, Inkatha and the rest ...", pp. 325-360

15 Forsyth, "The Past in the service of the present", p. 74.

16 See, for instance, a version of this claim in Buthelezi, M, Speech delivered at the unveiling of the tombstone of Dr Pixley ka Isaka Seme. Newclare Cemetery, Johannesburg, 15 September 1984. See also Mare and Hamilton, An appetite for power. 


\section{BUTHELEZI'S APPRORIATION OF SEME'S POLITICAL LEGACY}

On 15 September 1984, Buthelezi stood at Newclare Cemetery in western Johannesburg to unveil the tombstone of Seme. This was an extraordinary event for, although Buthelezi was known to align himself with the founders of the ANC, he had not before taken as bold a step as erecting a tombstone of the founder of the ANC. Buthelezi's intentions for erecting the tombstone soon became clear: at the head of the tombstone were the following words, "The stone has been erected by his family and Inkatha Yenkululeko Yesizwe", and only at the tail end were added the words, "Founder of African National Congress in 1912". ${ }^{7}$ The inscription on the tombstone, as well as the speech he delivered at the ceremony, laid bare his political motives.

In the speech, Buthelezi made a strong claim to familial, social and political association with Seme. He stated that Seme was his maternal uncle, due to the fact that Seme's wife, Princess Phikisile ka Dinuzulu, was his mother's halfsister and therefore his aunt. Buthelezi drove home the point about this familial association when he stated that he was paying tribute to Seme not just as "an ordinary African", but also as "someone who shares the blood which beat so nobly in his veins". ${ }^{18}$ He pressed his advantage by reciting anecdotes of his numerous encounters with Seme as a family member. He stated that, "Seme was not a legend of some distant uncle somewhere". ${ }^{19}$ He claimed that in the 1940 s Seme stayed at Nongoma where he dictated (to Buthelezi to write), "a pile of correspondence which I took down in long hand". ${ }^{20}$ Buthelezi also told a story (which he tells all the time) of the letter Seme wrote to ZK Matthews, a professor at the University of Fort Hare where Buthelezi was a student at the time, about Buthelezi's expulsion from the campus. Buthelezi claimed that Seme's letter to Matthews on his behalf,

“... stands for all time to answer all those amongst my detractors who pretend as if my leadership in KwaZulu was created by the homelands policy. Dr Seme states, as you see, who I am and what my family's leadership position in KwaZulu had always been."21

17 For discussion of the significance of Buthelezi erecting the tombstone of the founder of the ANC see Ngqulunga, B, The man who founded the ANC: A biography of Pixley ka Isaka Seme. Cape Town: Penguin Books, 2017).

18 See page 2 of Buthelezi, Speech delivered at the unveiling of the tombstone of Dr Pixley ka Isaka Seme. The claim that Buthelezi carried Seme's blood in his veins simply because Seme was married to his aunt is rather bizarre.

19 Buthelezi, Speech delivered at the unveiling of the tombstone of Dr Pixley ka Isaka Seme, p. 10

20 Ibid.

21 Ibid., p. 11. 
Seeking to justify his decision to operate within the Bantustan system and not join the ANC and other liberation organisations in exile, Buthelezi suggested, rather tenuously, that he was following in the footsteps of Seme. He claimed that Seme would have disagreed, "violently with those who think that they can direct the people's struggle from distant countries". ${ }^{22}$ Unlike the leaders of what he had come to call the ANC's "mission in exile", Buthelezi claimed that Seme had returned to South Africa, after his studies overseas so that he could be with his people. He alleged that Seme would have stayed with the people in South Africa especially when the apartheid government became more provocative, and adopted harsher methods to oppress black people. Then he delivered this coup de grace,

"Dr Pixley ka Isaka Seme would never once, even though he lived a million years, have sipped whiskey in a luxury hotel in Europe or North America while he used the ordinary people, and used the ordinary youth here, as cannon fodder." 23

What this speech clearly demonstrates is that Buthelezi was enlisting Seme's name to support his political position that were coming under increasing attack from his political opponents in the ANC leadership, as well as from its allies at home. In addition, Seme was a perfect figure for deployment by Buthelezi in his political warfare. They had a familial relationship, which allowed Buthelezi to stake a strong claim on Seme's legacy. Seme's political record is moderate, if not conservative, which allowed Buthelezi to justify his own conservative politics by invoking Seme's. Significantly, Buthelezi used Seme's political record and that of the founders, such as Dube, to make an argument that the only legitimate politics of the ANC was his politics. One issue on which he explicitly enlisted Seme, by invoking his conservative political record, was over the ANC decision to embark on the armed struggle, a position that Buthelezi opposed. He labelled those who supported the armed struggle as representing, what he called, the stream of despair in black politics, which expressed itself in confrontation, challenge and violence. ${ }^{24}$ The alternative brand of politics, which he claimed he and Seme represented, was the stream of hope, which, in his view, was stronger than the stream of despair. The stream of hope, he contended, manifested itself in the politics of representation, of negotiation and of democratic opposition to apartheid. ${ }^{25}$ His reduction of black politics into the two streams and his claim that the founders of the ANC always followed his chosen stream, while very simplistic, 
is better understood as a stratagem on his part to rationalise his politics amidst fierce competition from his political opponents at the time.

It was not for the first time that Buthelezi had invoked the name of Seme and other leaders of the ANC to support his claim to political leadership. For instance, in May 1984, he made a bold claim that his political party, Inkatha, represented and embodied the whole political tradition of the struggle for liberation in South Africa. He asserted,

"Inkatha is Black South Africa undivided, standing together, pursuing the time-honoured traditions of Black South Africa...For us, Black South African political traditions go back to 1912 when the African National Congress was formed. I stand boldly before you and say that those are the traditions that Black South Africa serves. Those are the traditions, which Inkatha serves."26

Buthelezi claimed that his various associations with past leaders of the ANC rooted him in the tradition of the black liberation struggle. He drove this point home by stating,

'Dr Pixley ka Isaka Seme was my uncle. He was one of the founding fathers of the ANC. I grew up at my mother's knee learning what he and others did. When I became older, I joined the ANC. I knew people like Nelson Mandela, Robert Sobukwe and Oliver Tambo personally. I knew what their faces looked like. I know what their voices sound like and I know what the feel of their hands in my hands feels like. My own ambitions were to become a lawyer, but it was Chief Albert Luthuli himself who said that my duty lay with the people and that I should not indulge in the luxury of what I wanted to do...The great leaders of South Africa when I was a young man recognized that I was destined to do what I am now doing. My father and his father before him served successive Zulu Kings as Prime Ministers and for me there was no escape from this hereditary role unless I was to betray my people and seek my own selfish ends away from them. Thus, comrades when I say I serve Black South Africa's political traditions, I say that with sureness and with power. These traditions run in my blood and I did not create my own blood. I was born into this world with the blood coursing through my veins carrying the traditions of the people." ${ }^{27}$

The passage cited above, like his speech at the unveiling of Seme's tombstone in September 1984, captures Buthelezi's claim to what he considered to be his historical mandate to lead not only Inkatha, but also the black liberation struggle as a whole. Like he had done before and he would continue to do in

26 Buthelezi cited in Mare and Hamilton, An appetite for power, p. 220

27 Ibid., p. 220. 
the future, Buthelezi's claim was that he derived the mandate to lead from his association with past ANC leaders such as Seme, Luthuli, Mandela, Tambo and Sobukwe. He in fact claimed that he had been convinced by Luthuli to take up the chieftaincy of the Buthelezi tribe and to participate effectively in the Bantustan system. He also claimed that he derived his right to lead and rule from a tradition, which laid a responsibility on the Buthelezis to become Prime Ministers to Zulu kings.

His version of history was not left uncontested. The contestation came from both the ANC and its domestic allies, such as the UDF and COSATU. Presenting the political report of the National Executive Committee of the ANC at its meeting in Kabwe, Zambia, in 1985, Tambo conceded that the ANC was aware and agreed with Buthelezi about the need to form Inkatha in 1975. ${ }^{28}$ The ANC hoped that by supporting Buthelezi's participation in the Bantustan system and in the formation of Inkatha, Tambo reported, he would use the legal avenues available to mobilise the oppressed majority against the apartheid system. Tambo decried the ANC's failure to mobilise its membership inside South Africa to turn Inkatha into an organisation the ANC hoped it would be by supporting its formation. This failure allowed Buthelezi to use Inkatha and the structures of the Bantustan system to build his own power base. Tambo predicted that Buthelezi's political manoeuvres would fail, but conceded once again, that he (Buthelezi) was the ANC's "fault". 29 The ANC allies at home were not as forgiving to Buthelezi and as diplomatic as Tambo was. Initially the leadership of the UDF sought to forge common ground with Buthelezi and his Inkatha, others in the leadership even contemplating a situation in which Inkatha could even join the UDF as an affiliate. ${ }^{30}$

The intense political competition and the violence that accompanied it between members of the UDF and Inkatha, especially in Natal in the 1980s, undermined any prospect of cooperation between the UDF and Inkatha. As the violence escalated, the ANC's domestic allies denounced Buthelezi and Inkatha as traitors, who collaborated with the apartheid system. ${ }^{31}$ Progressive academics, sympathetic to the ANC and its domestic allies and critical of Buthelezi, exposed the many fallacies peddled by Buthelezi to buttress his political ambitions. For instance, in February 1987 University of Natal academics, Gerhard Mare and Georgina Hamilton published a scathing book on Buthelezi and his Inkatha, which laid bare his political ambition and the mobilisation of Zulu ethnic identity for political ends. ${ }^{32}$ Mare and Hamilton's book was followed by Mzala's book, which

28 Tambo, Oliver [compiled by Adelaide Tambo], Oliver Tambo Speaks (Cape Town: Kwela Books, 2017), pp. 223-224.

29 Ibid., p. 225.

30 Seekings, The UDF, p.64.

$31 \quad$ Ibid., p. 65.

32 Mare and Hamilton, An appetite for power. 
challenged the fundamental tenets of Buthelezi's historical claims to leadership, including his long standing assertion that the Buthelezis have always occupied the position of traditional Prime Minister to Zulu kings. Mzala also challenged Buthelezi's appropriations of the names of past ANC leaders to justify his political positions. ${ }^{33}$ Buthelezi's response to Mzala's rebuttals was to threaten legal action to any library which carried the book. ${ }^{34}$

The important point to underscore about these claims and counterclaims is that they are best understood within the context of intense political competition between rival political organisations. Buthelezi's resort to appropriating Seme's name, should also be understood in this political context. When the political context changed after the advent of democracy in the 1990s, his political rhetoric and political claims also changed. While he continued to invoke Seme's name, he did so not to draw a line between himself and the ANC. Instead, he pointed to Seme to claim for himself a political lineage in the ANC. The purpose of reclaiming the ANC heritage was no longer to gain political dominance, but to appeal to the judgment of history.

\section{BUTHELEZI AND THE JUDGMENT OF HISTORY}

The advent of democracy in South Africa in the early 1990s, which culminated in the democratic elections in April 1994, saw Buthelezi gradually changing his tune and abandoning virulent ethnic nationalist politics. ${ }^{35}$ As Piper argues, part of the reason Buthelezi changed was because of the inclusion of the IFP in the Government of National Unity (GNU). ${ }^{36}$ The new democratic institutional arrangements that regulated the conduct of political engagement also set boundaries about what kinds of political behaviours were acceptable and those which were not. Buthelezi was forced to act within those boundaries that defined appropriate political behaviour. The ANC also encouraged Buthelezi's forays into inclusive political rhetoric and behaviour. One of the most notable gestures that the ANC extended to Buthelezi was the attendance and address by Thabo Mbeki of the IFP Annual General Conference, held at Ulundi in July 1998. While the attendance on its own was quite significant, considering the violent conflict between the supporters of the ANC and the IFP, what Mbeki said in his address was equally, not more, significant. Mbeki stated that his attendance of the IFP conference constituted a clear message that the ANC wanted to put behind the

\footnotetext{
33 Mzala, Gatsha Buthelezi.

34 For a detailed discussion of Buthelezi's legal threats against Mzala's book and the universities' reaction to the legal threat, see Wyley C and C Merrett, "Universities and the New Censorship: Mzala's Gatsha Buthelezi: Chief with a Double Agenda", Critical Arts 5(4), 1991, pp. 98-115. See Piper, Nationalism without a nation, p.86.

$36 \quad$ Ibid., p.77.
} 
conflict it had had with the IFP. He said the ANC had read the presence of Lionel Mtshali, the chairperson of the IFP at the time, at its 1997 National Conference also as a sign of the IFP's sincerity in mending its relations with the ANC. In a clear attempt at stroking Buthelezi's legendary ego, Mbeki called Buthelezi his political senior having joined the ANCYL earlier than him and referred approvingly to the formation of Inkatha ka Zulu - the predecessor to the IFP-by elements in the Zulu Royal House, supported by John Langalibalele Dube. Mbeki also claimed to have personally interacted with Buthelezi about the decision to form Inkatha in the 1970s. ${ }^{37}$ Mbeki's courtship of Buthelezi reached the highest point when he offered Buthelezi the position of Deputy President of the country in 1999. ${ }^{38}$ Although Buthelezi was ultimately not appointed to the position, due to differences over the Premiership of KwaZulu-Natal, Buthelezi continued to moderate his political stances and to gradually move towards the ANC. ${ }^{39}$

It also appeared that he (Buthelezi) was increasingly worried by how he would be judged by history. This became very evident in the lead up to the ANC centenary celebrations that took place in Bloemfontein on 8 January 2012. Two days before the celebrations, Buthelezi issued a public statement in which he reiterated his relationship with Seme, whom he called his uncle. He asserted strongly his political roots in the ANC and argued that the formation of Inkatha had the blessing's of the ANC. ${ }^{40}$ Abandoning his political posture of the September 1984 speech in which he had distanced himself from the ANC of Tambo and Mandela; in January 2012, he embraced those leaders. He said,

"I grew up in the ANC Youth League at the University of Fort Hare. I was taught by Professor ZK Matthews, I knew Dr John Langalibalele Dube, I was mentored by Inkosi Albert Luthuli, and I worked closely with $\mathrm{Mr}$ Oliver Tambo and Mr Nelson Mandela. My personal history cannot be extricated from the history of the liberation struggle, or from that of the African National Congress." 41

37 Mbeki, T, Speech to the Annual General Conference of the IFP, Emandleni, KwaZulu-Natal, 18 July 1998, <http://www.mbeki.org/2016/06/08/speech-to-the-annual-general-conference-ofthe-ifp-emandleni-kwazulu-natal-19980718/>.

38 See Temkin, B 2003. Buthelezi: A biography (London: Frank Cass, 2003), p. 351. See also Mbeki's interview with the Daily News, "Mbeki offer to Buthelezi "unconditional'": https://www.iol.co.za/ news/politics/mbeki-offer-to-buthelezi-unconditional-40283.

39 See the report on the details of the reasons behind Mbeki's failure to appoint Buthelezi as his deputy: "Mbeki fails to nominate Buthelezi as SA's deputy president": https://www.irishtimes. com/news/mbeki-fails-to-nominate-buthelezi-as-sa-s-deputy-president-1.197069.

40 Buthelezi, M, "I grew up in the ANC Youth League - Mangosuthu Buthelezi". www.politicsweb. co.za 6 January 2012.

$41 \quad$ Ibid. 
Buthelezi worried that the history of his association with the ANC and the role he played in fighting against apartheid was not known. He expressed his worry thus,

"The younger generation is seldom told that Inkatha was founded on the original ideals of the ANC, from which we have never deviated. They are not told that Inkatha adopted the colours and symbols of the ANC because it was created to pick where the ANC left off when it was banned and when its leaders went into exile. Few know that I quoted Mandela wherever I went, when doing so was against the law, or that I held more rallies under the banner "Free Mandela" than anyone else in South Africa." 42

Buthelezi had come full circle; he had gone back to the politics of Inkatha of the early 1970s, which projected itself as the continuation of the ANC. He also quoted several ANC leaders who had commended him for his role in fighting the apartheid system, and for the contribution he was making in the consolidation of democracy and the building of the nation in South Africa. Among leaders he claimed had praised him were former president Mbeki and Cleopas Nsibande, one of the 1956 Treason Trialists and a prominent leader of the ANC in what is known today as Mpumalanga and Gauteng Provinces. ${ }^{43}$ He decried the fact that the national chairperson of the ANC at the time, Baleka Mbete, had not afforded the IFP an opportunity of a meeting in order to discuss its role in the centenary celebrations prior to the big event that took place in Bloemfontein. On several occasions in the centenary year of the ANC, Buthelezi used every occasion to associate himself with the ANC and its leaders. One such occasion was the birthday of Mandela. Buthelezi used the occasion to issue a public statement in which he detailed his friendship with Mandela, which he claimed dated many decades. He expressed his gratitude to Mandela for appointing him acting President of the Republic "22 times", whenever Mandela and his deputy, Mbeki, were simultaneously out of the country. ${ }^{44}$ Also, in the year 2012, Buthelezi issued a public statement in which he gave his interpretation of the history for liberation in South Africa. He put himself and the Zulu Royal House at the centre of that history by stating,

"The struggle of the Zulu nation for liberation from colonial oppression became the roots of South Africa's liberation struggle. The liberation struggle was in fact born out of the Zulu Royal household. My mother's sister, Princess Phikisile, King Dinuzulu's firstborn, married Dr Pixley ka

44 See Buthelezi, M, "Buthelezi honours Mandela", 2012, <https://www.iol.co.za/news/specialfeatures/nelson-mandela/birthdays/buthelezi-honours-mandela-1344407>. 
Isaka Seme. In 1912, Dr Seme founded the South African National Native Congress, which became the ANC. In the 1920s, my uncle, King Solomon ka Dinuzulu, established Inkatha ka Zulu, a national movement to restore national consciousness and pride. He was joined in this initiative by Dr Seme and Dr John Langalibalele Dube, the first President of the ANC."45

In this statement Buthelezi was staking a claim in the pantheon of the liberation struggle, going as far as even to make an extraordinary claim that the very roots of the struggle were entrenched in the Zulu Royal House with which he is related through his mother, Princess Magogo ka Dinuzulu, and his uncle by marriage, Seme. By mentioning the founding of Inkatha by his uncle, Solomon ka Dinuzulu, Buthelezi was effectively arguing that his Inkatha of the 1970s was a reincarnation of the organisation of the 1920s, founded by Solomon and Dube. This claim was similar to Mbeki's assertion when he addressed the IFP Conference in 1998. In the same statement, Buthelezi claimed to have been supported by Inkosi Albert Luthuli, AWG Champion and Masabalala Yengwa, all prominent leaders of the ANC in Natal at the time, when he took up the position of the inkosi of the Buthelezi clan. ${ }^{46}$

What is noteworthy about Buthelezi's political statements in 2012 and beyond, in relation to the ANC and its leaders, is that he was trying to position himself as one of the leaders of the ANC. Where he had disagreements with the ANC about his political choices, he argued that those choices either received the blessings of venerated leaders of the ANC or were in pursuit of its original ideals. The ultimate purpose of this political position was an attempt at influencing the judgment of history. Although he continued to appropriate the name and politics of Seme and other venerated ANC leaders such as Dube, Luthuli and Mandela, he was doing so not as a virulent opponent of the ANC. The appropriation was in pursuit of locating himself in the mainstream of the black liberation tradition

As the ANC's political fortunes appeared to decline during the presidency of Jacob Zuma and it was constantly embroiled in scandal, Buthelezi once again employed the name of Seme and other former ANC leaders to criticise the ANC leadership. He accused the ANC of being corrupt and of deviating from the path that was laid by Seme. ${ }^{47}$ It appears that Buthelezi was trying to exploit the vulnerabilities of the ANC for the benefit of his party during the municipal elections of August 2016 and several by-elections that took place in KwaZulu-

45 Buthelezi, M, "Reflections on my ousting", 2012, <http://www.polity.org.za/print-version/ifpstatement-by-mangosuthu-buthelezi-president-of-the-inkatha-freedom-party-on-southafrican-wicket-keeper-mark-bouchers-eye-injury-12072012-2012-07-12>. Ibid.

47 Buthelezi, M "Corrupt ANC a far cry from the organisation he once served, says IFP leader", 11 June 2017, <https://www.timeslive.co.za/politics/2017-06-11-corrupt-anc-a-far-cry-fromorganisation-he-once-served-says-ifp-leader/>. 
Natal in 2017. In a speech he gave at a political rally in Phongolo, a small town in northern KwaZulu-Natal during a campaign for a by-election, Buthelezi invoked Seme's name to attack the ANC. He charged that,

"We have lost respect for what the ANC has become. Promise by broken promise, we have lost faith in a party that barely resembles the liberation movement started by my uncle, Dr Pixley ka Isaka Seme. I look at the ANC now, and I wonder how it could have fallen so far from the organisation I once served. The answer of course is corruption. Once you open the door to that, the floodgates open to all kinds of evil."48

Buthelezi had made a similar point in February 2013 when he welcomed the formation of Agang SA, a political party founded by Dr. Mamphela Ramphele. He argued that the ANC at the time was, "no longer the party of the 1912 visionaries; the party of Dr Pixley ka Isaka Seme, Inkosi Albert Luthuli and Nelson Mandela". He charged that the "ANC is corrupt and it is failing South Africa". ${ }^{49}$ In this instance, like in other instances, Buthelezi used Seme's name as a stick with which to beat up the ANC. The timing of the statement is important to understand what he was trying to achieve. The statement was issued a year before the general elections in 2014. Like similar statements he issued in 2016 during the campaign for municipal elections, the 2013 statement and the use of Seme's name was intended to discredit the leadership of the ANC by comparing it to the ANC leaders of old. His intention was to persuade those who would vote in the general elections in 2014 to abandon the ANC and vote for his political party, the IFP. The results of the 2014 general elections, which the ANC soundly won, suggest that Buthelezi's political gambit did not succeed.

Buthelezi's statements in the lead up to the general elections in 2014 and the local government elections in 2016 share some similarities with his rhetoric in the 1980s, where he claimed to be the standard-bearer of the political tradition of the ANC of 1912, distinguishing it from what he routinely called the ANC Mission in Exile. In the lead up to the elections in 2014 and 2016, he also sought to distinguish between the ANC led by Jacob Zuma and the ANC of Seme and other founders. The purpose in this case was to convince the electorate, especially disillusioned ANC supporters, that Zuma's ANC had abandoned the values and mission of the 1912 ANC as founded by Seme; he and his IFP represented that political tradition.

\footnotetext{
$48 \quad$ Ibid.

49 Buthelezi, M, "IFP: Statement by Mangosuthu Buthelezi, Inkatha Freedom Party President, online letter", 22 February 2013, <http://www.polity.org.za/print-version/ ifp-statement-by-mangosuthu-buthelezi-inkatha-freedom-party-president-onlineletter-22022013-2013-02-22>.
} 


\section{CONCLUSION}

The discussion in this article shows the consistency with which Buthelezi has used Seme's name to claim a mandate to lead not only the IFP, but also the whole black liberation struggle. He has also invoked the names of other venerated leaders of the liberation struggle, such as Luthuli, Tambo, Mandela and Sobukwe, to justify his various controversial political positions, including his participation in the Bantustan system. Part of the reason Seme is easily available for appropriation by Buthelezi is because of their familial relationship. Their politics is also not extremely different. Seme was a self-confessed political conservative who preferred to work within the institutions of government in representing the interests of black people, which is the same approach that Buthelezi adopted. Although Seme was a committed African nationalist who worked for black unity, there were moments when he articulated political positions that were evidently narrow Zulu nationalist. ${ }^{50}$ While scholars such as Mzala, Couper, Sithole and Mkhize, and Mare and Hamilton, have correctly called out Buthelezi on his use of the names of former leaders of the ANC, either to claim the right to lead the liberation struggle or to justify his controversial political positions; it is important to also highlight that some of Buthelezi's claims were not completely farfetched.

I have also shown in this article that Buthelezi's appropriation of Seme's name and legacy did not end with the advent of democracy. He continued to invoke Seme and other venerated leaders of the ANC. The purpose for the appropriation was different. He used their names to claim for himself a respectable position in the pantheon of the black liberation struggle, which was led by the ANC. The public statements he issued in the lead up to the ANC centenary in 1912, where he decried what he considered the public's ignorance about his past membership of the ANC Youth League and his association with past ANC leaders, point to a leader who desperately wanted the judgment of history to be favourable to him. Even in cases where he has sought to distance himself from the ANC in the recent past, the purpose has been to win votes, rather than to rewrite history as he sought to do in the 1980s.

50 For a discussion of Seme's lapse to narrow Zulu nationalism, see chapter 5 of Ngqulunga, The man who founded the ANC. 